\title{
Recognizable Elements of the Mass Communication
}

\author{
Oprea-Valentin Buşu, Oana-Cristina Buşu \\ University of Bucharest, Bulevardul Regina Elisabeta 4-12, Bucharest 030018, Romania \\ E-mail address: valentino_busu@yahoo.ro
}

\begin{abstract}
The study is focused on understanding and synthesizing of some specificity of mass communication. After reviewing of the relevant opinions concerning the mass communication, on meta-analytic way are differentiated three elements of the recognizable of the mass communication concept: semantic node 1 - the mass communication messages are public, semantic node 2 - the transmission flows to the channels of communication are fast and large and semantic node 3 - the recipient of the messages is massive, heterogeneous and anonymous.
\end{abstract}

Keywords: mass communication; mass-media; press; journalism

\section{INTRODUCTION}

The term mass communication usually designates, a number of techniques and transmission networks that allow put in readiness of a vast public of an important set of messages. It is often used as a synonym for the mass media, especially by American researchers, the latter being formed from the Latin term media (means) and the English word mass, thereby indicating that they are means addressing a massive public and undifferentiated. Among the synonyms of media we meet other terms like: social media, mass media, public and collective diffusion techniques, normally, combining mass media: journalism, radio, television, cinema and poster (McQuail, 1987; McQuail, 2010; Borowski, 2013a).

The two expressions are however not equivalent, although their confusion became a daily stereotype, because by the mass communication is designated not only a set of means or techniques, but a highly complex social process, institutionalized process, organized and social regulated. It should also be noted that within the spectrum of forms of communication (intrapersonal, interpersonal, organizational, etc.) mass communication not only differs by an order of magnitude (Dima, Grabara \& Vlăduţescu, 2012).

Relative to this last specific feature, it should be noted that the mass term has not pejorative connotation or qualificatory for the public quality or the conveyed messages and is not either an exclusive quantitative distinction, because we can not establish a threshold beyond which we can say that we have a mass audience. The term designates a social process, a communication relationship between specialized institutions and an undifferentiated public, unorganized, consisting of separate individuals from point of view physically and who have no the possibility of a common response.

Mass Communication is the set of modalities (networks of transmission, individual and autonomous equipment) which allows making available to a rather wider audience of a 
plurality of messages, regardless of form or purpose. American sociologists prefer to this expression the term "mass-media" (Larousse Dicţionar de Sociologie, 1996; Buşu, 2010; Nowicka-Scowron, Dima \& Vlăduţescu, 2012).

\section{MASS COMMUNICATION SPECIFICITY}

Social communication takes different forms. First, spontaneous and nonaxiomatic, does not seem to obey any other rule, except social habit; it is part of interpersonal relationships, limited, poor, crafted, spontaneous, and prescriptive. At the other extreme, inter-and intraorganizational relationships are led by institutions: between nations, between cities, between companies, between governor and governed, within each social organization and outside them. Institutionalized communication defines the economic, social and political regime which society is endowed, that brings us closer to communities in its original meaning: community (Milca, 2005; Bădescu, 2011; Vlăduţescu, 2013a). Mass communication must be located between these two forms of social communication. Its uniqueness belongs to appealing of using techniques with different degrees of sophistication, available for the establishment and amplification of dialogue between individuals or groups that constitute it. Certainly, mass communication depends also of the nature of a particular culture. But it has no autonomy, no equivalent of a constituent principle; only occupying the space vacated by interpersonal and institutionalized communication, accepting instead the possibility of influence each one, it becomes what one and the other, together, allow and want to be (Turow, 2011; Tittenbrun, 2014).

The sociologists attention has focused, from the appearence of major daily newspapers, in the early twentieth century, about the study of mass media influence: the influence of the press, radio and television on the behavior and attitudes of all and each one. Before 1920, they considered each of the favorable effects of extending in the greatest number of this privilege able to "communicate" with all, due multiplication of books and newspapers. The interwar period shows increasing degradation of culture and society, both subject of the influence of new means of mass communication, especially cinema and radio. T. W. Adorno, one of the representatives of the Frankfurt School, evoke this "stylized barbarity" toward which is opened, according to him, the progressive industrialization of the culture (Vlăduţescu, 2004; Vladutescu, 2006).

The sociology of communications acquires a radically different orientation along with C. Hovland and P. Lazarsfeld, several years before the Second World War. Designed during F. D. Roosevelt campaign in 1940, Lazarsfeld's study (1944) opposes an outright denial of opinions about refugees vote. Because the results examination of a sampling survey among the voters, the study demonstrates that these finally vote as those in their entourage. Emphasizing the importance of personal contacts on the undecided, the survey identifies opinion leaders, true intermediaries between the public and high media. The success of this trial opened the way of a certain development of sociological studies that confirm its conclusions. Since 1960 are multiplied warnings against the claims of researchers to solve the problem of the influence of mass media, through the surveys or limited observations. The M. McLuhan and J. Ellul's essays, from 1962-1964, marks profoundly the thought. The professor McLuhan refers to media analysis of their technical characteristics and of the way in which mobilize their users' opinions "the message is the medium". J. Ellul is questioning the relevance of the American studies, his concept was too mechanistic vision related of the action of communication means: the "propaganda" object comes before the propagandist. He 
refers to the examination of the psociety, its organization and the various conditions that favor the emergence of propagandas.

At the same time with the emergence of the new interactive communication means, sociology today strives to analyze, simultaneously, the issues of communication, transmitters and receivers, as well as its purpose, every time another. Through an interactionist approach, it rediscovers that is important also what people expect from the mass communication, what they understand and what they think (Vlăduţescu, 2014c).

Mass communication means transmission of information by qualified specialists to a wider audience, diversified, spread on a vast territory. Is achieved through the mass media complex technical and organizational means, including particularly television, radio, movies, newspapers, books, periodicals and, in increasingly, the Internet (Johnson, 2007, p. 78). The Group communication involves the study of the group dynamics, while mass communication suppose the messages sent from mass sources, often for the purpose of mass making money (Oxford Dicţionar de Sociologie, 2003, p. 117). Mass communication is, by definition, a oneway process.

Since the first studies, in the $30 \mathrm{~s}$, the main concern was the involvement of the power in new media technologies, particularly radio and television. The successful use by Adolf Hitler of radio propaganda was a clear example of the potential dangers. The concept of mass society has reinforced the idea that electronic media can create a situation of Orwellian mind control, dominated passive masses by a small elite of communicators (Măgureanu, 2003; Măgureanu, 2009; Frigioiu, 2008).

The modern image of the mass society starts without to be so entitled, with the French aristocrat Alexis de Tocqueville, who traveled to the United States in the 1830s searching for the secret of the democracy. He was surprised by the similarity of ideas and values of the people and said that such a society could fall victim to a mass mentality, or of majority, which he called the "tyranny of the majority". Tocqueville's classic description of the mass society has influenced the whole further history of the social theory: "... a multitude of men", all equal and alike, incessantly seeking to satisfy petty pleasures that saturates their lives. Each of them taken separately, is alien to the fate of others (Harris, 2009; Vlăduţescu \& Ciupercă, 2013).

Children and his friends are to him the whole of mankind. As for the rest of the friends citizens, is close to them but he doesn't see them, he touches them but he doesn't feel them. Sociologists of XIXth century shared many of Tocqueville's ideas on appearence of the industrial society cultures. Emile Durkeim has seen the anomia behind the new order, and Max Weber was concerned of the impersonal nature of bureaucracy. Ferdinand Tonnies (1887) did not look at all friendly societies crowded, urban, of mass that appeared in Europe.

These ideas have been largely ignored or labeled as nostalgic and elitist to the '50s, when sociologists and political scientists began to study the history of the last years of totalitarianism in Europe and in the Soviet Union. In work The Politics of Mass Society (1959), William Kornhauser argued that free populations living in stable communities, in which have uniform and coherent values, may be vulnerable to the appeal power of the totalitarian mass movements.

Further researches revealed that a mass communication is mediated in different ways, its effects on the audience depending on factors such as class, social context, values, beliefs, emotional states, even also the time of day (Siminică \& Traistaru, 2013).

In case of mass communication the individual effects of the transmitted messages by an external source are not direct, but intermediated by the social structure of the group, the same transmitter disposing of transmitting possibilities of the same message to a large number of potential receptors. These possibilities are offered by technical means of mass 
communication, respective press, radio and television (Traisatru, 2013; Cotoc, Traisatru \& Stioca, 2013).

Generally the study of mass communication has tended to focus on its component elements and the relations between them included in a synthetic form like: "who says what, through what channels (media) of communication, to whom and to what effect " $(\mathrm{H}$. D. Lasswell, 1946). Regarding the source, it was paid attention to the contextual organization of the message and audience image of transmitter, respective credibility given to this. In message organizing was distinguished between priority and last position of some information to reveal differential effects. The advantage of priority position consist in to strengthen the attitudes already held by receptors, whereas those included in the end of the message lies in stimulation of reflection and retention increase (Vlăduţescu, 2013b; Vlăduţescu, 2013f)).

Meanwhile, the effects depend also on the awareness by receptor of transmission intention, by the complexity and repeatability of the message. For example, awareness of transmission intention decreases the intensity and extension of the effects and the too complex messages produce only surface effects because they are not decoded. Insistent repeating of communication of the same messages towards the same people produces a saturation of reception expressed disinterest of messages, a high degree of intentional conformism and a compensated search of messages come from other sources.

The effects of mass communication means are the most often indirect, in the sense that their influences are strengthened or weakened by the group structure and especially by the leaders of opinions from the affiliation groups (Frigioiu, 2009; Francis.Dominick, 2011). At the same time of multiplication of mass communication means increased audience and exposure grade, but also the personal selectivity, simultaneous with passivity emphasizing in receiving. Although their informative effects may increase, the formative and especially those generating of actions are reduced. Generally, the mass communication effects depend on previous predispositions and attitudes of recipients (Dicţionar de Sociologie, 1998; Jason L. Powell, 2013).

Mass communication requires the obligatory presence of the gate-keeper. He is presented as a institutionalized producer of messages addressed to some unknown recipients. Although it takes forms of the various (production of books, journalism, radio or television broadcasting) this kind of communication is characterized in all cases by poor presence of feed-back, incomplete and much delayed compared to that of interpersonal communication or public areas (Cottle, Negrine, Newbold \& Halloran, 1998; Vlăduţescu, 2013c).

There is of course the possibility of a reverse connection: post editorial, phones available to the public, but the magnitude and the impact of retroaction remain modest. Besides, people addressing mass media organizations are often not, the most representative of the preferences and opinions of the mass consumers, but simply those that have the most free time. Among the most important functions of the mass media can be mentioned as follows (Dinu, 2007, p. 112): information function, which satisfies an undeniable human need, but also causes to the receiver caught in game a real information bulimia, of which effect may be discernment blurring, that can lead to some form of passivity installing, apathy, paralysis of the will to understand and act that Paul Lazarsfeld and R. K. Merton called it "narcotic dysfunction".

Interpretation function, manifested both explicitly through journalistic productions like editorial or commentary, the first expressing the official point of view of the press organ, while the second makes known to the public only the personal views of its author, and an implicit manner, but no less effective, consisting of selecting transmitted information and in 
setting of some priorities, perceived by receptors as true hierarchy of importance (Vlăduţescu, 2013d; Vlăduţescu, 2013e).

Instructive culturalization function covers both explicit providing of cultural and scientific knowledge, as in the case of documentaries and popularize science pages of periodicals, and to promote, in a less obvious, but the more persuasive, values, norms, behavior patterns related to the cultural paradigm of the society, whose stability contribute thus, at least in a negligible extent.

The binder function derives from previous, because individuals who possess a similarly base of information, are concerned with the same issues of timeliness and share common cultural and moral values will feel more close to each other and they will unite, in need, beyond the national borders, religious, political or racial, they mobilize in favor of worthy causes, perceived as the entire humankind (Bandura, 2002; Vlăduţescu, 2014a).

Entertainment function, responding to the desire of the stressed human relaxation of professional requirements, but also of the thirst for escape in an imaginary universe of misfits, invaded by so much mass media content that tends to become the second nature of them. Not only that, percentage, the broadcasts or pages dedicated to relaxation and entertainment are growing, but more than that, there is a more marked orientation to treatment in terms of performance of all issues approached by the mass communication means (Borowski, 2013c; Donovan A. McFarlane, 2013). Television, but also other media organizations turn in show any situation that is presented. The danger of moral of such an attitude lies in the risk of cultivating to receiver a certain "aesthetic detachment" in relation to the serious problems of reality, not perceived in their true size just because their presentation on the coordinates of the show, way that tends to blur the boundaries between reality and fiction (Măgureanu, 2006).

\section{CONCLUSIONS}

There are four specific features of mass communication:

a. It is a social institution that includes a series of activities executed by qualified personnel, designed to meet a general requirement for modern society: quickly and constant information of the individual, and some derivatives (create link channels between the individual and society, production and sharing of the knowledge, "furnishing" of the public space);

b. Messages are public;

c. Speed in transmission of messages is another important feature, and a performance index, an old newspaper only of few days is keeping a documentary or archival value;

d. Reception of the messages assumes existence of a broad audience, heterogeneous and anonymous. Being a social institution that includes communication activities carried out by qualified personnel, even specialized. 


\section{References}

[1] Borowski A. (a), International Letters of Social and Humanistic Sciences 3 (2013) 69-74.

[2] McQuail, D. (1987). Mass communication theory: An introduction. Sage Publications, Inc.

[3] McQuail D. (2010). McQuail's mass communication theory. Sage Publications.

[4] Donovan A. McFarlane, International Letters of Social and Humanistic Sciences 4 (2013) $35-44$.

[5] Jason L. Powell, International Letters of Social and Humanistic Sciences 7 (2014) 22-30.

[6] Borowski A. (b), International Letters of Social and Humanistic Sciences 2 (2014) $110-121$

[7] Vlăduţescu Ştefan (2004). Argumentaţia şi demonstraţia, ca moduri de impunere. Craiova: Editura Sitech.

[8] Vlăduţescu Ştefan (a), Jokull Journal 63(8) (2013) 186-197.

[9] Frigioiu N. (2009). Antropologie politică. Bucureşti: Editura Tritonic.

[10] Francis Dominick J. R. (2011). Dynamics of Mass Communication: Media in Transition. McGraw-Hill Higher Education.

[11] Baran S. J., Davis D. K. (2010). Mass communication theory: Foundations, ferment, and future. Cengage Learning.

[12] Vlăduţescu Ştefan, Ciupercă, Ella Magdalena (2013). Next Flood Level of Communication: Social Networks. Aachen: Shaker Verlag.

[13] Harris R. J. (2009). A cognitive psychology of mass communication. Taylor \& Francis.

[14] Turow J. (2011). Media today: an introduction to mass communication. Taylor \& Francis.

[15] Dima Ioan Constantin, Vlăduţescu Ştefan (a), European Journal of Business and Social Sciences 1(6) (2012) 27-33.

[16] Tittenbrun J., International Letters of Social and Humanistic Sciences 2 (2014) 20-40.

[17] Dima Ioan Constantin, Vlăduţescu Ştefan (2012b). Persuasion elements used in logistical negotiation: Persuasive logistical negotiation. Saarbrucken: LAP Lambert Academic Publishing.

[18] Vlăduţescu Ştefan (b), American International Journal of Contemporary Research 3(10) (2013).

[19] Borowski A. (c), International Letters of Social and Humanistic Sciences 4 (2013) 70-74.

[20] Vlăduţescu Ştefan (b), International Letters of Social and Humanistic Sciences 5 (2014) 81-86.

[21] Traistaru Aurelia, Jokull Journal 63(9) (2013) 125-135.

[22] Bandura A., Social cognitive theory of mass communication. Media effects: Advances in theory and research 2 (2002) 121-153. 
[23] Vlăduţescu Ştefan (c), International Letters of Social and Humanistic Sciences 6 (2014) 49-54.

[24] Măgureanu V. (1997). Studii de sociologie politică. BucureŞti: Editura Albatros.

[25] Vlăduţescu Ştefan (d), International Letters of Social and Humanistic Sciences 7 (2014) 8-13.

[26] Măgureanu V. (2006). Sociologie politică. Bucureşti: Editura Rao.

[27] Vlăduţescu Ştefan (e), International Journal of Education and Research, 1(11) (2013).

[28] Milca, M. (2001). Geneza teoriei elitelor. Provocarea neomachiavellienilor. Bucureşti: Editura Economică.

[29] Vlăduţescu Ştefan (f), International Journal of Education and Research 1(12) (2013).

[30] Nowicka-Scowron Maria, Dima Ioan Constantin, Vlăduţescu Ştefan, International Journal of Management Sciences and Business Research 1(8) (2012) 27-35.

[31] Vlăduţescu Ştefan (2006). Comunicare jurnalistică negativă. Bucureşti: Editura Academiei.

[32] Cotoc E. A., Traistaru A., Stoica A., European Journal of Humanities and Social Sciences 25(1) (2013).

[33] Măgureanu V. (2003). Declinul sau apoteoza puterii. Bucureşti: Editura Rao.

[34] Vlăduţescu Ştefan (2004). Argumentaţia şi demonstraţia, ca moduri de impunere. Craiova: Editura Sitech.

[35] Vladutescu Stefan (2006). Comunicare jurnalistica negative. Editura Academiei Romane, Bucuresti.

[36] Măgureanu V. (2009). De la regimul comunist la regimul Iliescu. Bucureşti: Editura Rao.

[37] Milca M. (2005). Identitate românească şi europeană. Bucureşti: Editura Agir.

[38] Frigioiu N. (2008). Imaginea publică a liderilor şi instituţiilor. Bucureşti: Editura Comunicare.ro

[39] Buşu O.-C., (2010). Putere şi influenţă în organizaţii. Reconstruind Socialul. Riscuri şi solidarităţi noi. http://cluj2010.files.wordpress.com/2010/11/paper-oana-busu-ro.pdf

[40] Cottle S., Negrine R., Newbold C., Halloran J. D. (1998). Mass communication research methods. London: Macmillan.

[41] Vlăduţescu Ştefan (f), Jokull Journal 63(9) (2013) 301-318.

[42] Bădescu I. (2011). Sociologie rurală. Bucureşti: Mica Valahie.

[43] Johnson A. (2007). Blackwell Dicţionar de Sociologie. Bucureşti: Humanitas.

[44] Oxford Dicţionar de Sociologie (2003). Bucureşti: Univers Enciclopedic.

[45] Larousse Dicţionar de Sociologie (1996). Bucureşti: Univers Enciclopedic.

[46] Dicţionar de Sociologie (1998). București: Babel. 
[47] Dima, Ioan Constantin, Grabara, Janusz, \& Vlăduţescu, Ştefan, Journal on Business Review 2(2) (2012) 4.

[48] Dinu M. (2007). Comunicare. Repere fundamentale. București: Orizonturi.

[49] Siminică Marian, Traistaru Aurelia, International Journal of Education and Research 1(12) (2013). 